Pacific Journal of Mathematics

A GENERALIZATION OF MARTINGALES AND TWO 


\title{
A GENERALIZATION OF MARTINGALES AND TWO CONSEQUENT CONVERGENCE THEOREMS
}

\author{
Louis H. Blake
}

\begin{abstract}
Loeve has observed that a discrete stochastic process can be interpreted as a game and that a martingale can be interpreted as a "fair" game. In this context, the notion of a martingale is enlarged to a game which becomes "fairer with time" and then this concept is utilized to establish two convergence theorems.
\end{abstract}

Let $(\Omega, \mathfrak{N}, p)$ be a probability space with $\left\{\mathfrak{A}_{n}\right\}_{n \geq 1}$ an increasing family of sub $\sigma$-algebras of $\mathfrak{A}$ to which the process $\left\{X_{n}\right\}_{n \geqq 1}$ is adapted, (see [3, p. 65]). Henceforth, the process $\left\{X_{n}\right\}_{n \geqq 1}$ will be referred to as a game.

Definition. The game $\left\{X_{n}\right\}_{n \geqq 1}$ will be said to become fairer with time if for every $\varepsilon>0$.

$$
\left.p_{\mathbf{L}}^{r}\left|E\left(X_{n} \mid \mathfrak{A}_{m}\right)-X_{m}\right|>\varepsilon\right] \rightarrow 0
$$

as $n, m \rightarrow \infty$ with $n \geqq m$.

It should be noted that any martingale is a game which becomes fairer with time. An easy example of a game which is not a martingale or a sub or a super martingale but does become fairer with time is constructed by considering a game which consists of tossing a die. Here, let

$$
\mathfrak{U}_{n}=\mathfrak{N}, \text { all } n
$$

and

$$
X_{n}(\{i\}) \equiv i+(-1)^{n} / n
$$

The main results. Let $\left\{\alpha_{n}: n \geqq 1\right\}$ be a monotonic sequence decreasing to zero with finite sum. The game $\left\{X_{n}\right\}_{n \geqq 1}$ may be decomposed with respect to $\left\{\alpha_{n}: n \geqq 1\right\}$ as

$$
X_{n}=Y_{n}-Z_{n} \text {, where }\left\{Y_{n}\right\}_{n \geqq 1} \text { and }\left\{Z_{n}\right\}_{n \geqq 1}
$$

are defined inductively by:

$$
\begin{aligned}
& Y_{1}=X_{1} \\
& \vdots \\
& Y_{n}=Y_{n-1}+\left[X_{n}-E\left(X_{n} \mid \mathfrak{A}_{n-1}\right)\right]+\alpha_{n-1}
\end{aligned}
$$




$$
Z_{n}=Z_{n-1}+\left[X_{n-1}-E\left(X_{n} \mid \mathfrak{U}_{n-1}\right)\right]+\alpha_{n-1} .
$$

We note that $\left\{Y_{n}\right\}_{n \geqq 1}$ is adapted to the sequence of $\sigma$-algebras $\left\{\mathfrak{U}_{n}\right\}_{n \geqq 1}$ and forms a submartingale with respect to it.

We will call the decomposition of the game $\left\{X_{n}\right\}_{n \geqq 1}$ according to (1.1) - (1.3) a Doob-like decomposition. (See [3, p. 104-105].)

Also, we define the collection of sets $\left\{B_{n, m}^{\alpha}\right\}$ for $m=1,2, \ldots$ and $n \geqq m$ by

$$
B_{n, m}^{\alpha} \equiv\left\{w:\left|E\left(X_{n} \mid \mathfrak{Q}^{m}\right)-X_{m}\right|>\alpha_{m}\right\} .
$$

THEOREM 1. Let $\left\{X_{n}\right\}_{n \geqq 1}$ be a uniformly integrable game and $\left\{Y_{n}\right\}_{n \geqq 1}$, the submartingale associated with its Doob-like decomposition, be uniformly dominated in absolute value by an element of $L_{1}(\Omega, \mathfrak{A}, p)$. Suppose for every $\delta>0$ there exists an integer $N(\delta)$, such that

$$
P\left[B_{n, m}^{\alpha}\right]<\delta \text { whenever } n \geqq m \geqq N(\delta),
$$

and

$$
\sim B_{n, m}^{\alpha} \subset \sim B_{k, k-1}^{\alpha} \text { whenever } n \geqq k \geqq k-1 \geqq m \geqq N(\delta) \text {. }
$$

Then, there exists a function $X$ in $L_{1}(\Omega, \mathfrak{U}, p)$ such that

$$
\lim _{n \rightarrow \infty} \int_{\Omega}\left|X_{n}-X\right| d p=0 \text {. }
$$

Proof. It will be sufficient to show the game $\left\{X_{n}\right\}_{n \geqq 1}$ is Cauchy in the $L_{1}$ norm. For every pair $(n, m)$ of positive integers write:

$$
\int_{\Omega}\left|X_{n}-X_{m}\right| d p=\int_{B_{n, m}^{\alpha}}\left|X_{n}-X_{m}\right| d p+\int_{\sim_{n, m}^{\alpha}}\left|X_{n}-X_{m}\right| d p .
$$

Since $p\left[B_{n, m}^{\alpha}\right] \rightarrow 0$ as $n, m \rightarrow \infty$ and since the game $\left\{X_{n}\right\}_{n \geqq 1}$ is uniformly integrable (see [1, p. 89]), it is immediate that $\int_{B_{n, m}^{\alpha}}\left|X_{n}-X_{m}\right| d p$ can be made arbitrarily small for sufficiently large $n$ and $m$.

By utilizing the Doob-like decomposition of $\left\{X_{n}\right\}_{n \geq 1}$, we can write

$$
\int_{\sim B_{n, m}^{\alpha}}\left|X_{n}-X_{m}\right| d p \leqq \int_{\sim B_{n, m}^{\alpha}}\left|Y_{n}-Y_{m}\right| d p+\int_{\sim B_{n, m}^{\alpha}}\left|Z_{n}-Z_{m}\right| d p .
$$

Since there exists an integrable function which uniformly dominates the process $\left\{Y_{n}\right\}_{n \geqq 1}$ in absolute value, it is immediate that $\left\{Y_{n}\right\}_{n \geqq 1}$ is a convergent submartingale. Moreover, the dominated convergence theorem can be used to show that $\int_{\sim B_{n, m}^{\alpha}}\left|Y_{n}-Y_{m}\right| d p$ can be made arbitrarily small for sufficiently large $n$ and $m$. 
Thus, it remains to show that $\int_{\sim_{n, m}^{\alpha}}\left|Z_{n}-Z_{m}\right| d p$ can be made arbitrarily small for sufficiently large $n$ and $m$ and the proof will be complete.

On $\sim B_{n, m}^{x}$ it follows that

$$
X_{m} \geqq E\left(X_{n} \mid \mathfrak{U}_{m}\right)-\alpha_{m}
$$

In particular, on $\sim B_{n, n-1}^{\alpha}$

$$
X_{n-1} \geqq E\left(X_{n} \mid \mathfrak{I}_{n-1}\right)-\alpha_{n-1}
$$

and so where

$$
Z_{n}-Z_{n-1}=X_{n-1}-E\left(X_{n} \mid \mathfrak{A}_{n-1}\right)+\alpha_{n-1}
$$

we can say

$$
Z_{n}-Z_{n-1} \geqq 0 \text { on } \sim B_{n, n-1}^{\alpha} .
$$

Thus, choose any $\delta>0$ and there exists $N(\delta)$ such that

$$
\sum_{k=m}^{\infty} \alpha_{k}<\delta / 2 \text { for } m \geqq N(\delta)
$$

and such that (1.5) holds. Hence, with $n \geqq m \geqq N(\delta)$, (1.5) and (1.7), write

$$
Z_{n}-Z_{n-1} \geqq 0 \text { on } \sim B_{n, m}^{\alpha} \text {. }
$$

By observing the fact that $B_{n, m}^{\alpha} \in \mathfrak{A}_{m}$ for all $n$ and $m$, we can write that

$$
\int_{\sim B_{n, m}^{\alpha}}\left|Z_{n}-Z_{m}\right| d p=\int_{\Omega} E\left\{\left|Z_{n}-Z_{m}\right| I_{\sim B_{n, m}^{\alpha}} \mid \mathfrak{A}_{m}\right\} d p
$$

By (1.9), $\left|Z_{n}-Z_{m}\right| I_{\sim B_{n, m}^{\alpha}}=\sum_{k=m+1}^{n}\left(Z_{k}-Z_{k-1}\right) I_{\sim_{n, m}^{\alpha}}^{\alpha}$; this together with (1.6) lets us continue the equality in (1.10) to

$$
\begin{aligned}
\int_{\sim B_{n, m}^{\alpha}}\left|Z_{n}-Z_{m}\right| d p & =\sum_{k=m+1}^{n}\left\{\int_{\sim B_{n, m}^{\alpha}} E\left\{\left(X_{k-1}-E\left(X_{k} \mid \mathfrak{U}_{k-1}\right)+\alpha_{k-1} \mid \mathfrak{A}_{m}\right\}\right\} d p\right. \\
& =\int_{\sim B_{n, m}^{\alpha}}\left\{\left(X_{m}-E\left(X_{n} \mid \mathfrak{U}_{m}\right)\right)+\alpha_{m}+\cdots+\alpha_{n-1}\right\} d p \\
& \leqq \int_{\sim B_{n, m}^{\alpha}}\left\{\alpha_{m}+\sum_{k=m}^{n-1} \alpha_{k}\right\} d p<\delta
\end{aligned}
$$

By not demanding that the submartingale $\left\{Y_{n}\right\}_{n \geqq 1}$ associated with the Doob-like decomposition of the game $\left\{X_{n}\right\}_{n \geqq 1}$ be uniformly bounded above in absolute value by an element of $L_{1}(\Omega, \mathfrak{A}, p)$, we get the weaker 
THEOREM 2. Let $\left\{X_{n}\right\}_{n \geqq 1}$ be a uniformly integrable game satisfying (1.4) and (1.5). Then, there exists some constant $c$ such that

$$
\lim _{n \rightarrow \infty} \int_{\Omega} X_{n} d p=c
$$

Proof. It will be sufficient to show the sequence $\left\{\int_{\Omega} X_{n} d p\right\}_{n \geqq 1}$ is Cauchy. With respect to the Doob-like decomposition of $\left\{X_{n}\right\}_{n \geqq 1}$, we can write

$$
\left|\int_{\Omega}\left(X_{n}-X_{m}\right) d p\right| \leqq\left|\int_{B_{n, m}^{\alpha}}\left(X_{n}-X_{m}\right) d p\right|+\left|\int_{\sim B_{n, m}^{\alpha}}\left(X_{n}-X_{m}\right) d p\right| \cdot
$$

Again, $\left|\int_{B_{n, m}^{\alpha}}\left(X_{n}-X_{m}\right) d p\right|$ may be made arbitrarily small for sufficiently large $m$ and $n$ by using the uniform integrability of $\left\{X_{n}\right\}_{n \geqq 1}$. In order to deal with the second summand in (1.11), write

$$
\left|\int_{\sim B_{n, m}^{\alpha}}\left(X_{n}-X_{m}\right) d p\right| \leqq\left|\int_{\sim B_{n, m}^{\alpha}}\left(Y_{n}-Y_{m}\right) d p\right|+\int_{\sim B_{n, m}^{\alpha}}\left|Z_{n}-Z_{m}\right| d p .
$$

But $\int_{\sim_{n, m}^{\alpha}}\left|Z_{n}-Z_{m}\right| d p$ can be made arbitrarily small for sufficiently large $m$ and $n$ exactly as in the proof of Theorem 1 . Hence, showing that $\left|\int_{\sim B_{n, m}^{\alpha}}\left(Y_{n}-Y_{m}\right) d p\right|$ can be made arbitrarily small for sufficiently large $m$ and $n$ will complete the proof. To this end, we use (1.2) and write

$$
E\left(\left(Y_{n}-Y_{m}\right) \mid \mathfrak{I}_{m}\right)=\alpha_{m}+\cdots+\alpha_{n-1}
$$

and get

$$
\begin{aligned}
\int_{\sim B_{n, m}^{\alpha}}\left(Y_{n}-Y_{m}\right) d p & =\int_{\sim B_{n, m}^{\alpha}} E\left\{\left(Y_{n}-Y_{m}\right) \mid \mathfrak{I}_{m}\right\} d p \\
& =\int_{\sim B_{n, m}^{\alpha}}\left(\alpha_{m}+\cdots+\alpha_{n-1}\right) d p \leqq \sum_{k=m}^{n-1} \alpha_{k} .
\end{aligned}
$$

But since $\sum_{k=m}^{n-1} \alpha_{k}$ can be made arbitrarily small for sufficiently large $m$ and $n$, the result follows.

\section{BIBLIOGRAPHY}

1. K. L. Chung, A Course in Probability Theory, Harcourt, Brace \& World, Inc., New York, New York, 1968.

2. M. Loeve, Probability Theory, third edition, Van Nostrand, Princeton, New Jersey, 1963. 
3. P. A. Meyer, Probability and Potentials, Blaisdell Publishing Company, Waltham, Massachusetts, 1966.

Received March 20, 1970.

NORTHERN ILLINOIS UNIVERSITY

Worcester Polytechnic Institute 



\section{PACIFIC JOURNAL OF MATHEMATICS}

\section{EDITORS}

\author{
H. SAMELSON \\ Stanford University \\ Stanford, California 94305

\section{Richard Pierce} \\ University of Washington \\ Seattle, Washington 98105
}

J. DugundJI

Department of Mathematics

University of Southern California

Los Angeles, California 90007

RichaRd ARENS

University of California

Los Angeles, California 90024

\section{ASSOCIATE EDITORS}
E. F. BECKENBACH
B. H. NeUMANN
F. WOLE
K. YoshidA

\section{SUPPORTING INSTITUTIONS}

\author{
UNIVERSITY OF BRITISH COLUMBIA \\ CALIFORNIA INSTITUTE OF TECHNOLOGY \\ UNIVERSITY OF CALIFORNIA \\ MONTANA STATE UNIVERSITY \\ UNIVERSITY OF NEVADA \\ NEW MEXICO STATE UNIVERSITY \\ OREGON STATE UNIVERSITY \\ UNIVERSITY OF OREGON \\ OSAKA UNIVERSITY \\ UNIVERSITY OF SOUTHERN CALIFORNIA
}

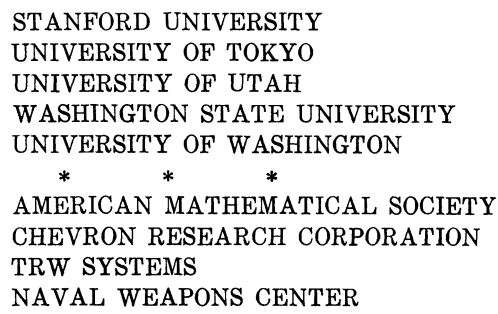

The Supporting Institutions listed above contribute to the cost of publication of this Journal, but they are not owners or publishers and have no responsibility for its content or policies.

Mathematical papers intended for publication in the Pacific Journal of Mathematics should be in typed form or offset-reproduced, (not dittoed), double spaced with large margins. Underline Greek letters in red, German in green, and script in blue. The first paragraph or two must be capable of being used separately as a synopsis of the entire paper. The editorial "we" must not be used in the synopsis, and items of the bibliography should not be cited there unless absolutely necessary, in which case they must be identified by author and Journal, rather than by item number. Manuscripts, in duplicate if possible, may be sent to any one of the four editors. Please classify according to the scheme of Math. Rev. Index to Vol. 39. All other communications to the editors should be addressed to the managing editor, Richard Arens, University of California, Los Angeles, California, 90024.

50 reprints are provided free for each article; additional copies may be obtained at cost in multiples of 50 .

The Pacific Journal of Mathematics is published monthly. Effective with Volume 16 the price per volume (3 numbers) is $\$ 8.00$; single issues, $\$ 3.00$. Special price for current issues to individual faculty members of supporting institutions and to individual members of the American Mathematical Society: $\$ 4.00$ per volume; single issues $\$ 1.50$. Back numbers are available.

Subscriptions, orders for back numbers, and changes of address should be sent to Pacific Journal of Mathematics, 103 Highland Boulevard, Berkeley, California, 94708.

PUBLISHED BY PACIFIC JOURNAL OF MATHEMATICS, A NON-PROFIT CORPORATION

Printed at Kokusai Bunken Insatsusha (International Academic Printing Co., Ltd.), 7-17, Fuj̣imi 2-chome, Chiyoda-ku, Tokyo, Japan. 


\section{Pacific Journal of Mathematics}

\section{Vol. 35, No. $2 \quad$ October, 1970}

Valentin Danilovich Belousov and Palaniappan L. Kannappan, Generalized Bol functional equation .................................... 259

Charles Morgan Biles, Gelfand and Wallman-type compactifications ........... 267

Louis Harvey Blake, A generalization of martingales and two consequent convergence theorems .................................... 279

Dennis K. Burke, On p-spaces and $w \Delta$-spaces..................... 285

John Ben Butler, Jr., Almost smooth perturbations of self-adjoint operators . . . . . . 297

Michael James Cambern, Isomorphisms of $C_{0}(Y)$ onto $C(X) \ldots \ldots \ldots \ldots \ldots . \ldots 307$

David Edwin Cook, A conditionally compact point set with noncompact closure ... 313

Timothy Edwin Cramer, Countable Boolean algebras as subalgebras and homomorphs .........................................

John R. Edwards and Stanley G. Wayment, A v-integral representation for linear operators on spaces of continuous functions with values in topological vector spaces.............................................

Mary Rodriguez Embry, Similarities involving normal operators on Hilbert

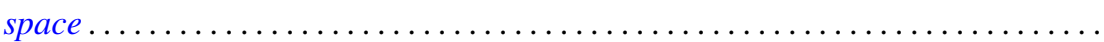

Lynn Harry Erbe, Oscillation theorems for second order linear differential

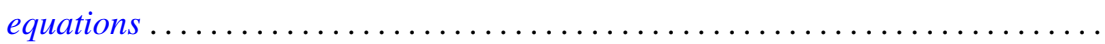

William James Firey, Local behaviour of area functions of convex bodies .......... Joe Wayne Fisher, The primary decomposition theory for modules ..............

Gerald Seymour Garfinkel, Generic splitting algebras for Pic ..................

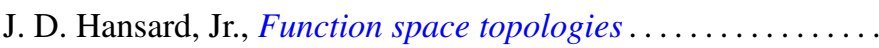

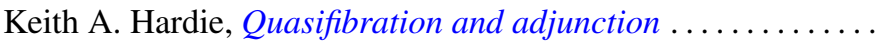

G. Hochschild, Coverings of pro-affine algebraic groups ...........

Gerald L. Itzkowitz, On nets of contractive maps in uniform spaces ..

381

389

399

417

Melven Robert Krom and Myren Laurance Krom, Groups with free nonabelian subgroups....................................

James Robert Kuttler, Upper and lower bounds for eigenvalues by finite differences ......................................

Dany Leviatan, A new approach to representation theory for convolution transforms . . .

Richard Beech Mansfield, Perfect subsets of definable sets of real numbers ...

Brenda MacGibbon, A necessary and sufficient condition for the embedding of a

Lindelof space in a Hausdorff $\mathscr{H} \sigma$ space ..................

David G. Mead and B. D. McLemore, Ritt's question on the Wronskian ....

Edward Yoshio Mikami, Focal points in a control problem .....

Paul G. Miller, Characterizing the distributions of three independent n-dimensional random variables, $X_{1}, X_{2}, X_{3}$, having analytic characteristic functions by the joint distribution of $\left(X_{1}+X_{3}, X_{2}+X_{3}\right)$. . .

P. Rosenthal, On the Bergman integral operator for an elliptic partial differential equation with a singular coefficient....

Douglas B. Smith, On the number of finitely generated $O$-group 